\title{
Lords report echoes concerns on NHS reforms
}

Britain's House of Lords has come to the support of the UK biomedical research community as it tries to protect its research activities from being undermined by the government's determination to place the administration of the National Health Service (NHS) on a more commercial footing.

The Department of Health, which runs the NHS, has already taken some steps to protect research from the short-term accountability now being demanded of those who manage health funds. But medical schools remain worried that the moves do not go far enough, and that their research activities remain at risk.

Last year, Virginia Bottomley, then secretary of health, took a major step toward safeguarding research and development (R\&D) funded by the NHS from the socalled internal market - the procedure initiated in 1990 by which physicians and local health authorities now 'purchase' health care from hospitals at the lowest possible price (previously local administrative decisions were taken separately from those on funding, which were decided more centrally).

Bottomley announced that the Department of Health was to pull together all the different types of research funded by the NHS into a single 'funding stream', financed by a levy on the budget of all health authorities. This fund was then to be 'ring-fenced' to protect its resources from being used to meet other health service needs, such as for hospital buildings.

The move to unify and protect research spending stemmed from proposals in an earlier wide-ranging report issued last year by a government-appointed task force, which was headed by Anthony Culyer of the University of York.

At the time, Britain's medical schools welcomed the Culyer report's recognition of the strategic importance of clinical research and the need to defend it against short-term pressures on those who now 'purchase' health care to keep their costs as low possible.

The Culyer report explicitly warned that "it is essential to separate funds for $R \& D$ and for service support (indirect costs) from $R \& D$ for other activities. Only by such a separation can health R\&D be properly identified, managed and accounted for, and only by such greater clarity can one be sure that in-

vestment in $R \& D$ will not be squeezed out as providers seek to keep their service prices to purchasers as low as possible."

But they also expressed nervousness that the reforms threatened to undermine their own research activities by allowing, through the 'single-stream' mechanism, other types of research - for example, that carried out by general practitioners - to compete for research funds previously allocated to medical schools (see

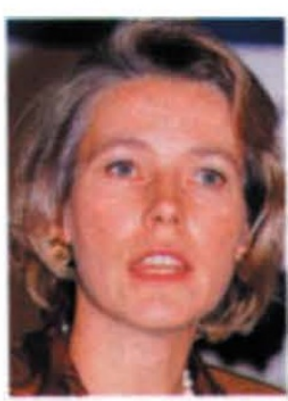

Virginia Bottomley, former UK health minister.

in general can be protected, the Lords committee warns that, unless care is taken when implementing these principles, the future of academic clinical research remains under threat.

If taken to extremes, warns the report, there could be a major shift in research resources away from long-term projects towards those meeting more immediate health needs, and this could mean the end of "curiosity-driven research in the major university hospitals," the Lords committee states in its report.

Such concerns are widely shared by those working in universities. John Bell, for example, professor of medicine at the University of Oxford, points to the dilemma facing physicians and local health authorities, who are now responsible for 'purchasing' health care, over where to send patients.

With the costs of referring a patient to an academic hospital, which has to meet the extra overhead costs of the research, being considerably higher than for a district hospital, he says, purchasers are increasingly reluctant to make such referrals. "Unless money gets properly directed to support [academic hospitals], we have quite a serious problem," says Bell, pointing out that the extra costs of teaching hospitals have up to now been covered out of central NHS funds. "If we do not continue to receive the subsidies which are necessary to run a really firstclass institution, we are completely cooked."

The Lords report makes a number of recommendations. These include the following:

- Steps to place limits on the extent to which funds for research are targeted to a relatively few university hospitals. The committee wants all such hospitals, which currently receive special funds to support research from the government, to be "guaranteed a level of core funding from the $R \& D$ budget" after these special funds are absorbed into the single research funding stream.

- An allowance for curiosity-driven research to be added on to NHS R\&D grants, in addition to the money intended for identified goals. The committee says that "curiosity[-]driven research" should not be considered an indulgence or an optional extra".

- An immediate enquiry into the disincentives to a career in academic medicine.

The government had yet to provide an official response to the Lords report. But Sir Michael Peckham, director of R\&D for the NHS (and, as such, responsible to Bottomley for commissioning the earlier Culyer report and implementing its findings), says that he broadly welcomes its conclusions. He says that the government has already set up a number of committees to look into the type of problems identified in the report, including, for example, the effect that changes in the way that patients are referred to hospitals might have on research.

With these and other developments in the health department, Peckham says that "all the building blocks are in place for addressing many of the points raised by the Lords committee," though adding that it is also up to the research community "to look at how it relates its research to the reconfiguration of the health service."

But the biomedical community is waiting to see what happens in practice before delivering its final verdict, particularly given that, without any substantial funding increase, additional support for research in some areas - such as general practice and community health - will inevitably mean less for others.

DAVID DICKSON London 